\title{
PENDIDIKAN KETERAMPILAN HIDUP (LIFE SKILL) ANAK USIA DINI SELAMA MASA PANDEMI COVID-19 DI LINGKUNGAN KELUARGA
}

\author{
Ghatarina Umi, M. ${ }^{1}$ \& Mila Karmila ${ }^{2}$ \\ 1,2 Pendidikan Guru Pendidikan Anak Usia Dini, Institut Universitas PGRI Semarang
}

\begin{abstract}
:
It is important to instill the stimulation of the child's ability to carry out self-help activities from an early age because it includes life skills that are needed to support his adulthood. This stimulation is usually implemented in Early Childhood Education institutions through habituation activities, but during the Covid-19 pandemic the government enforced a school learning policy at all levels, which is usually face-to-face to learning from home (BDR). The role of parents is very crucial for the growth and development of all aspects, especially in early childhood life skills education (life skills). The purpose of this paper is to describe how life skills education can be done in the family. The research method uses literature review of various relevant references. The results of the analysis obtained data that through simple habituation such as learning discipline, independence, creativity so that it can encourage children to foster the development of early childhood life skills.
\end{abstract}

Keywords: Life skills, Covid-19 pandemic, family environment.

\begin{abstract}
Abstrak:
Stimulasi kemampuan anak untuk melaksanakan aktivitas bantu diri (self help) penting ditanamkan sejak usia dini karena termasuk keterampilan hidup (life skill) yang sangat dibutuhkan untuk menunjang masa dewasanya. Stimulasi tersebut biasanya diimplementasikan di lembaga Pendidikan Anak Usia Dini (PAUD) melalui kegiatan pembiasaan, namun selama masa pandemi Covid-19 pemerintah memberlakukan kebijakan pembelajaran sekolah di semua jenjang yang biasanya tatap muka menjadi belajar dari rumah (BDR). Peran orang tua menjadi sangat krusial untuk tumbuh kembang semua aspek, terutama dalam pendidikan keterampilan hidup anak usia dini (life skill). Tujuan penulisan ini untuk mendeskripsikan bagaimana pendidikan keterampilan hidup yang dapat dilakukan di keluarga. Metode penelitian menggunakan kajian pustaka dari berbagai referensi yang relevan. Hasil analisis diperoleh data bahwa melalui pembiasaan sederhana seperti belajar disiplin, kemandirian, kreatif dapat mendorong anak menumbuhkan perkembangan keterampilan hidup anak usia dini.
\end{abstract}

Kata Kunci: Keterampilan hidup, pandemi Covid-19, lingkungan keluarga.

Artikel dengan akses terbuka dibawah license Creative Commons Attribution-NonCommercial 4.0 International License. (https://creativecommons.org/licenses/by-nc/4.0/) by penulis. Received: Oktober 2020, Accepted: Nopember 2020, Published: Desember 2020 


\section{PENDAHULUAN}

Sejak virus Covid-19 menyebar di Indonesia pada bulan Maret 2020 menyebabkan pemerintah tegas mengambil kebijakan Pembatasan Sosial Berskala Besar (PSBB) untuk mencegah terjadinya penyebaran virus Covid 19 yang semakin luas, wabah virus Covid 19 berbahaya yang dapat mengakibatkan infeksi saluran pernafasan, batuk, demam hingga menyebabkan kematian. Menurut pendapat Buana (2020:2), Covid-19 pada awal 2020 yang terjadi di Indonesia adalah fenomena yang sangat luar biasa yang menyebabkan banyaknya orang meninggal dunia, maka dari itu pemerintah melakukan berbagai cara agar penyakit tersebut tidak menular dan salah satunya adalah menerapkan physical distancing dan social distancing. Selain itu upaya lain yang diwajibkan untuk ditaati adalah menghindari kerumunan dan saat keluar wajib menggunakan masker. Menurut WHO (2019) dalam Cahyati (2020:2) Virus Covid-19 yang disebabkan oleh penularan antar manusia dan hewan, dengan gejala yang seperti flu hingga sesak pada pernafasan.

Adannya penyebaran virus Covid-19 ini yang terjadi di negara Indonesia menyebabkan semua sarana dan prasarana menjadi tutup sementara. Termasuk dalam kegiatan belajar yang tidak dapat dilakukan disekolah menjadi belajar dari rumah (BDR). Begitupun juga untuk orangtua yang harus mengikuti aturan pemerintah menerapkan bekerja dari rumah atau work from home (WFH). Kondisi tersebut telah merubah tatanan system sosial yang semula para keluarga beraktivitas penuh hari untuk bekerja, selama pandemi ini posisi peran keluarga semakin utuh karena keluarga lebih banyak beraktivitas di rumah dan dapat selalu berkumpul bersama sehingga keluarga juga akan lebih banyak berkesempatan untuk berinteraksi, memberikan pendampingan dalam belajar kepada anak-anaknya.

Peranan orang tua dirumah saat masa pandemi Covid-19 dalam hal pendidikan menjadi semakin terlihat pada anaknya saat dirumah, bagimana peran orang tua mendidik anak ketika dirumah terutama hal yang harus dilakukan oleh orang tua untuk mengajarkan dan memberi contoh kepada anak dalam kegiatan sehari-hari saat berada dirumah. Apa saja kebiasaan-kebiasaan yang diterapkan dalam keluarga khususnya dalam keterampilan hidup ( lift skill) yang dapat diterapkan orang tua dirumah melalui kemampuan beradaptasi dan sosialisasi yang positif. Menurut pendapat Permono (2013:2) peran orang tua adalah hal yang sangat kompleks terhadap peranan dalam keluarga untuk membentuk kepribadian dan karakter pada anak. Hal ini menunjukkan bahwa orang tualah madrasah pertama bagi anak-anaknnya dalam kegiatan belajar saat dirumah. Dapat diuraikan adannya belajar dari rumah hubungan antara orang tua dan anak dapat semakin erat karena orang tua adalah peran utama dalam keluarga dalam proses pertumbuhan dan perkembangan pada anaknya. Bisa dilihat untuk pertama kali lingkungan yang terdekat dengan anak untuk perkembangan skill dan kemampuannya dapat diterapkan dari kebiasaan orangtua dilingkungan keluarga. Maka dari itu peran orangtua dalam keluarga sangat penting bagi anak untuk proses perkembangan dan pertumbuhan yang optimal, keterampilan hidup yang telah dibentuk orang tua sejak usia dini akan menjadikan anak memiliki karakter yang positif melalui kebiasaan-kebiasaan pada setiap harinya ketika berada dirumah.

Salah satu kemampuan yang penting dan dapat ditanamkan oleh keluarga selama 
belajar dirumah oleh orang tua adalah pengembangan keterampilan hidup (life skill). Salah satu pengembangaan keterampilan hidup adalah aktivitas bantu diri (self help) seperti makan tanpa bantuan, mandi, dan membereskan tempat tidur. Aktivitas bantu diri tersebut dapat menstimulasi anak menjadi mandiri sebagaimana yang sering diterapkan guru saat berada disekolah seperti merapikan sepatu, merapikan tempat duduk, menaruh tas pada tempatnya hingga makan siang secara mandiri. Apakah banyak orang tua yang memberikan motivasi kepada anak tentang life skill hidup bagaimana tentang kebiasaan beraktivitas mandiri, cara orangtua mengajarkan kebiasaan mandiri seperti mulai saat bangun tidur merapikan tempat tidur, melipat selimut, mandi sendiri, memakai pakaian sendiri, makan sendiri, ambil minum sendiri, membereskan mainan sendiri dan hal positif yang lainnya tanpa bantuan orangtua, akan tetapi orangtua tetap melakukan pendampingan yang harus diperhatikan apalagi anak usia 4-5 tahun yang belum sepenuhnya dapat melakukan kegiatan sendiri tanpa pendampingan. Utami (2018) menyatakan bahwa anak usia dini merupakan individu yang berproses dalam pertumbuhan dan perkembangan secara pesat menuju untuk membentuk dalam kecakapan hidup yang lebih matang. Hal tersebut akan membentuk pola yang baik pada anak melalui kerampilan hidup yang diajarkan orangtua karena pola asuh yang positif membentuk individu yang mandiri dan kreatif.

Berdasarkan paparan diatas, dibutuhkan peran orang tua sebagai pengganti guru saat dirumah, peranan orang tua dalam kondisi pandemi Covid-19 ini dalam mendidik anak selama belajar dari rumah, terkait pendidikan keterampilan hidup yang diajarkan anak dirumah untuk menjadikan individu yang mandiri dan bertanggung jawab. Kegiatan yang diberikan oleh orangtua terhadap anak adalah pembentukan rasa percaya diri dan rasa tanggung jawab anak sehingga terbangun sejak usia dini. Berdasarkan uraian permasalahan tersebut penelitian ini akan mendeskripsikan dan menjelaskan tentang peran orang tua terhadap anak saat dirumah dalam masa pandemi Covid-19. Tujuan penelitian ini dapat mengetahui bagaimana peran orangtua dalam mengajarkan pendidikan life skill keterampilan hidup saat dirumah melalui pembiasaan-pembiasaan apakah pendidikan life skill dapat berjalan dengan optimal ataupun sebaliknya. Pendidikan keterampilan hidup pada anak usia dini adalah pendidikan yang harus diterapkan kepada anak sejak usia dini untuk membangun pengetahuan terhadap anak untuk melatih anak dalam kedisplinan, membentuk karakter, bertanggung jawab, dan memberi motivasi setiap apa yang dikerjakan anak untuk mencapai tumbuh kembang yang optimal. Seperti pendapat Sudarsana (2017:3) Keterampilan hidup pada anak usia dini adalah keterampilan kecakapan hidup yang harus dimiliki sejak usia dini karena hal tersebut sangat berpengaruh besar pada anak untuk dapat menolong atau mengurus dirinnya sendiri (self help) karena kebiasaan tersebut mulai ditanamkan sejak usia dini. Seperti yang diuangkapkan pendidikan keterampilan hidup Noor (2015:2) kecakapan hidup (life skill) bentuk proses pengembangan dalam kehidupan yang harus benar-benar diperhatikan melalui pendidikan kecakapan hidup untuk memberi bekal bagi anak untuk masa depan. Dengan melalui pembiasaan-pembiasaan pendidikan karakter, keterampilan hidup yang diterapkan pada keluarga akan menjadikan anak memiliki budi pekerti dan berdampak pada tumbuh kembang dan menjadi pribadi yang berkarakter. Dengan melalui pendidikan keterampilan yang diterapkan orangtua kepada anak sejak usia dini hal ini 
juga mengedukasi terhadap anak mengajarkan hal-hal yang positif agar kemandirian tersebut dapat menolong pada dirinya sendiri.

Lingkungan keluarga pada anak usia dini adalah tempat pendidikan pertama bagi anak untuk memberikan contoh keteladanan bagi anak dan berproses menjadi pribadi yang berkarakter. Peran orang tua dalam lingkungan keluarga sangat mengedukasi anak dalam menerapkan pola-pola kebiasaan anak dalam bersikap sabar, kedisiplinan, bertanggung jawab, dan selalu memberikan motivasi kepada anak. Seperti pendapat yang dikemukakan oleh Erzad (2017:4) dalam lingkungan keluarga adalah tempat utama anak mendapatkan pendidikan, tinggal bagiamana orang tua dalam mengajarkan pola asuh yang benar kepada anak karena lingkungan dan keluarga adalah bentuk dari penyesuaian pendidikan karakter anak. Adapun pendapat dari Purandina (2020:5) karakter dapat dibentuk melalui peranan dalam keluarga dari lingkungan keluarga karakter anak dibentuk. Adapun faktor bawaan yang dapat mempengaruhi, akan tetapi proses dari lingkungan yang akan banyak dianut anak secara terus-menerus contohnya adalah orang tua dalam keluarga. Lingkungan keluarga adalah kunci utama bagaiamana orangtua mengajarkan keterampilan hidup pada anak usia dini dan bagaimana kebiasaan orangtua yang sering diterapkan saat dirumah. Di lingkungan keluarga anak dapat belajar banyak tentang hal pendidikan keterampilan hidup bersama orang tua, semakin orang tua memberikan pola asuh yang benar dan positif semakin besar peluang anak akan bertumbuh dan berkembang menjadi individu yang kreatif dan mandiri.

\section{METODOLOGI}

Penelitian Metodologi penelitian yang digunakan adalah studi pustaka sebagai prosedur penelitian untuk mengkaji enam sampai sepuluh penelitian relevan terhadap apa yang diteliti mengenai pendidikan keterampilan hidup anak usia dini pada lingkungan keluarga, maka dari itu penulis ingin lebih jauh mengkaji tentang bagaimana pendidikan keterampilan hidup anak usia dini pada lingkungan keluarga selama masa pandemi Covid-19 berdasarkan kajian literatur. Terdapat beberapa definisi dari pengertian peran keluarga dalam keterampilan anak usia dini. Dari defisini pertama menurut Purandina (2020:5) bahwa lingkungan keluarga adalah lingkungan yang baik dalam perkembangan sikap karakter postif pada anak usia dini. Definisi yang kedua dikemukakan Lilawati (2021:4) peran orang tua adalah peran yang pertama sekaligus peran yang sangat penting dalam mendidik kedisiplinan anak hal tersebut harus ditanamankan kepada anak sejak usia dini. Defini yang ketiga dinyatakan oleh Dewi (2020:2) dalam keluarga pendidikan individu dimulai pertama bagi anak untuk membentuk anak dalam berproses tentang pendidikan kecakapan hidup melalui pembiasaan yang diterapkan orang tua saat dirumah. Definisi yang keempat dikemukakan oleh Cahyati (2020:6) dengan diadakannya belajar dari rumah selama pandemi Covid-19 peran orangtua sebagai pengganti guru saat dirumah dapat memberikan motivasi kemandirian pada anak sehingga orangtua lebih memahmi kemampuan pada anaknya saat melakukan kegiatan bersama dirumah.

Definisi yang kelima menurut pendapat Sudarsana (2017:6) dalam berumah tangga orang tua merupakan pendidikan nomor satu untuk anaknya bukan hanya untuk merawat dan membesarkan akan tetapi orangtua juga mendidik, menstimulasi mengajarkan berbagai pengetahuan salah satunya pendidikan keterampilan hidup pada anak saat 
dilingkungan keluarga. Definisi yang keenam dikemukakan oleh Erzad (2017:3) keterampilan hidup (life skill) dalam lingkungan keluarga adalah bentuk dari pendidikan yang harus diterapkan kepada orangtua saat dirumah agar anak memperoleh pengetahuan yang luas dan membentuk kepribadian yang berkarkter. Definisi yang ketujuh menurut pendapat Mutiyati (2020:10) dalam masa pandemi Covid-19 orang tua adalah jembatan pertama dalam mendidik kemampuan dalam belajar khususnya dalam pendidikan keterampilan hidup (life skill) orangtua dapat membimbing dan memberi motivasi pengganti guru disekolah, bagaimana orangtua dapat melihat kemampuan perkembangan pada setiap harinya tidak hanya itu kedekatan antara anak dan orang tua semakin erat dan terjalin semakin baik karena setiap hari dapat berkumpul bersama keluarga disaat masa pandemic Covid-19. Definisi yang kedelapan dikemukakan oleh Trisnawati (2021:2) faktor utama yang mendukung dalam keberhasilan anak dalam pendidikan keterampilan hidup (life skill) adalah keluarga, karena panutan anak dalam berkepribadian adalah orangtua bagaimana cara anak untuk melihat karakter yang diajarkan orangtua pada setiap harinya oleh karena itu orangtua penentu dalam keberhasilan anak untuk mempunyai kepribadian, karakter, kedisplinan dan tanggung jawab yang positif. Definisi yang kesembilan menurut pendapat Iftitah (2020:3) pada lingkungan keluarga adalah tempat anak untuk belajar dan berproses dalam membentuk kepribadian yang baik bagaimana orangtua berinteraksi dengan anak begitupun anak dengan orangtua untuk menjalin hubungan yang harmonis. Definisi yang ke sepuluh dinyatakan oleh A'yun (2016:2) peran orangtua dalam keluarga adalah salah satu kewajiban yang harus dilakukan dalam mendidik anak-anaknya untuk menjadikan anak yang teladan, mandiri serta bertanggungjawab. Berdasarkan uraian diatas dapat disimpulkan bahwa pendidikan keterampilan hidup (life skill) anak usia dini adalah berhubungan dengan kajian diatas yang mengenai pendidikan keterampilan hidup (lift skill) untuk mengetahui kebenarannya.

\section{HASIL DAN PEMBAHASAN}

Proses Menurut dari hasil yang diteliti dalam pendidikan keterampilan hidup (lift skill) anak usia dini selama masa pandemi Covid-19 di lingkungan keluarga dengan kebijakan pemerintah selama masa pandemi Covid-19 dengan menerapkan lockdown belajar dan bekerja dari rumah. Peran orangtua sangat penting dan diperlukan anak selama masa pandemi, tentu saat waktu bersama keluarga lebih banyak dan peran keluarga sangat besar dalam pendidikan keterampilan anak selama dirumah. Hal ini sangat berkesempatan baik bagi orangtua, karena orangtua dapat melihat secara langsung bagaimana proses perkembangan anaknya. Keluarga dirumah selama masa pandemi Covid-19 dapat memberikan contoh keteladanan kepada anak melalui pendidikan keterampilan hidup anak usia dini dengan melalukan pembiasaan-pembiasaan dalam proses pembentukan karakter adalah sebagai berikut :

\section{Menanamkan Kedisplinan}

Disiplin merupakan konsep yang menerapkan tindakan kepatuhan terhadap nilainilai peraturan tata tertib yang telah diterapkan. Sikap kedisiplinan sangat berpengaruh besar dalam proses pembentukan karakter, sikap disiplin juga dapat dipercaya dalam kehidupan untuk mewujudkan cita-cita. Menurut pendapat Kurniwan dalam penelitian 
Purandina (2020:11) mengemukakan bahwa negara kita memiliki peradaban dan memiliki budaya yang sangat tinggi dalam tingkat kedisiplinan. Sikap disiplin adalah suatu pembiasan dalam sehari-hari untuk menuju proses yang lebih baik dalam bertingkah laku terhadap ketertiban, kepatuhan, tanggung jawab, dan ketaatan.

Disaat masa pandemi pada saat ini, dalam tingkat kedisiplinan pada anak harus selalu dibentuk melalui pembiasaan-pembiasaan. Bagaimana peran orangtua saat dirumah dalam masa pandemi terhadap pengembangan kedisiplinan pada anak, karena saat pandemi ini adalah waktu yang sangat untuk dapat berkumpul bersama keluarga akan lebih banyak kegiatan-kegiatan yang bisa dilakukan bersama. Bagaimana pembentukan sikap disiplin pada anak dalam kegiatan sehari-hari anak selalu dilibatkan dalam setiap pekerjaan rumah bersama orangtua, contohnya: mencuci piring, menyapu, membersihkan tempat tidur, mengisi air dalam botol, membereskan mainan setelah bermain, kebiasaan mencuci tangan. Akan tetapi tidak semua kegiatan rumah diserahkan sepenuhnya kepada anak tetap saja ada proses pengawasan dari orangtua. maka hal tersebut saat melibatkan anak dalam kegiatan saat dirumah proses pembentukan karakter disiplin anak akan terbentuk. Seperti pendapat Ta'biin (2017:3) dalam pembiasaan disiplin anak akan memilki sikap yang unggul dan berkarakter akan sangat berpengaruh besar untuk kehidupan anak dimasa depan.

Menanamkan kedisplinan terhadap anak merupkan hal yang dapat mendorong anak untuk melakukan pencapaian yang positif dengan adanya dorongan-dorongan dari orangtua dengan konsep kedisiplinan akan berpengaruh besar terhadap anak saat dewasa, konsep disiplin tersebut adalah bekal untuk anak dimasa depan. Menurut pendapat Guntur (2018:5) disiplin merupakan suatu kondisi yang sudah terbentuk dengan serangkaian proses dari berbagai perilaku dengan berbagai konsep dan menunjukkan teratur, tertib, patuh, dan taat yang dibentuk melalui keluarga.

Dapat diuraikan dari kebiasaan melalui sikap disiplin yang diterapkan pada keluarga dirumah anak akan memiliki jiwa berpegang teguh dalam berkomitmen, jika anak sudah menjadi dewasa akan terbiasa menanamkan sikap kedisiplinan dalam peraturan seharihari sehingga anak tidak merasa kaget dalam menghadapi kehidupannya dan untuk bekal dimasa depan anak yang akan datang.

\section{Menanamkan nilai kreatif}

Kreatif adalah suatu kemampuan untuk menyelesaikan sebuah permasalah dengan serangkaian ide-ide gagasan yang dapat menghasilakan sebuah karya atau cipta yang sangat menarik, dengan demikian pendidikan karakter yang dilakukan menumbukan nilai kreatif akan membentuk karakter anak yang memiliki kepribadian ulet. Menurut Priyanto (2014:3) kreatif merupakah usaha yang harus dikembangkan saat sejak dini untuk menciptakan/menghasilan suatu yang baru melalui karya, kegiatan, dan gagasan.

Sebagai orangtua selama masa pandemi Covid-19 banyak waktu bersama dengan anak bagaimana mengajak anak untuk memberikan tugas yang dapat merangsang untuk berfikir dan bagaimana cara untuk menyelesaikan sebuah masalah tersebut seperti contoh mengajak anak untuk menanam bunga dan membuat taman bunga didepan rumah, dari situlah kita akan melihat anak dapat menyelesaikan masalah dari mulai mengisi tanah kedalam pot, menanam bunga, bagaimana agar bunga subur dan tidak layu diberi pupuk 
dan air. Bagaimana agar taman didepan rumah terlihat rapi anak mulai berkreasi untuk menata pot sesuai dengan ide kreatif. Serta orangtua harus selalu memberi dukungan dan semangat dan juga pengawasan, jika anak berhasil orangtua akan memberikan suatu penghargaan sederhana yang membuat anak merasa dirinya dihargai hal tersebut juga dapat melihat perkembangan anak sesuai dengan bakat dan minat yang dimilikinya. Mayar (2019:5) Kreativitas merupakan suatu kemampuan intelektual yang dimiliki manusia yang sering juga disebut dengan berfikir kreatif begitupun dengan anak usia dini yang memiliki kemampuan kreatif dapat memecahkan suatu masalah dan memunculkan ide-ide baru yang muncul dari imajinasi anak lalu dituangkan dan dikembangkan menjadikan sebuah karya cipta. Melalui pemberian motivasi dan perhatian dari orangtua, perkembangan kreativitas anak dapat terasah nilai karakter kreativitas akan terbentuk anak lebih mudah menyelesaikan suatu masalah dalam berfikir kritis.

Dalam suasana rumah yang nyaman dan keluarga yang hangat dapat mendukung perkembangan dan pertumbuhan anak menunjang kreatifitas. Karena dukungan dari keluarga adalah paling utama dan berperan penting, orangtua harus bersikap komperatif dalam membentuk karakter yang kreatif pada anaknya memberikan dukungan terhadap anak, selalu memberi motivasi, dan memberikan fasilitas dalam menujang keterampilan kreatif yang dibutuhkan oleh anak sesuai dengan bidang bakat dan minat terhadap anak. Menurut pendapat yulianti (2014:12) lingkungan keluarga adalah suasana yang paling nyaman untuk menunjang kreatifitas pada anak untuk bereksplorasi dengan kebebasan berkreasi dan berimajinasi sesuai dengan pola pikirnya. Dapat diuraikan kreatifitas merupakan suatu keterampilan hidup yang harus dituangkan dan dikembangkan untuk mengasah bakat dan minat pada anak. Melaui kreativitas anak dapat belajar banyak hal dalam memecahkan suatu masalah, berfikir kritis, dapat percaya diri, bersikap mandiri penuh inovatif dank solutif. Hal tersebut juga akan berdampak pada anak jika sudah dewasa mampu menghadapi setiap masalah yang ada dan dapat dipecahkan tanpa bergantung terhadap oranglain.

\section{Menanamkan Kemandirian}

Kemandirian adalah kemampuan untuk selalu berusaha dan tidak bergantung terhadap oranglain terhadap segala masalah atau mengambil sebuah keputusan yang sudah diambil dengan melalui berbagai pertimbangan dalam dirinya. Sa'diyah (2017:2) Kemandirian adalah mampu berfikir dan solutif dan dapat mengambil sebuah keputusan atau tindakan yang tepat yang dianggap mampu mengarahkan dirinya sendiri tanpa bergantung pada oranglain. Begitupun dengan anak usia dini untuk melatih kemandirian dalam pendidikan karakter mandiri yang diterapkan keluarga selama masa pandemi covid-19 dapat melatih anak belajar dan bersikap mandi untuk membangun perilaku tidak bergantung terhadap oranglain dengan sepenuhnya.

Menanamkan karakter mandiri terhadap anak usia dini adalah sikap yang paling penting dalam kehidupan anak, orangtua harus memberikan contoh dalam tindakan dalam kehidupan sehari-hari selama dirumah, apalagi dimasa pandemic ini sangat besar peluang waktu bersama keluarga. Sikap kemandirian tersebut bisa diterapkan dalam hal-hal yang sederhana saat mulai bangun tidur merapikan tempat tidur, melipat selimut, mandi sendiri, memakai baju sendiri, makan sendri, minum sendiri, cuci tangan sendiri, pipis 
sendiri dengan melalui pembiasaan-pembiasaan tersebut anak akan terbiasa melakukan kebiasaan mandiri dan dapat menolong dirinya sendiri, bukan berarti hal tersebut orangtua langsung lepas dalam pengawasan orangtua tetap memberi pengawasan terhadap anak selama melakukannya. Salah satu bentuk yang dilakukan orangtua ketika sudah berhasil melakukan tugas yang diberikan dalam menerapkan sikap kedisiplinan anak berhak mendapat reward dan apresiasi. Purandina (2020:13) Dalam mengembangkan nilai karakter kemandirian dapat menjadikan anak lebih berfikir positif bertanggung jawab atas segala tugas yang diberikan dikerjakan hingga selesai.

Dalam masa pandemi seperti sekarang ini orangtua memiliki peranan yang sangat besar terhadap keluarga dirumah khusunya pada anak-anaknya dalam membangun nilainilai karakter pada saat dirumah. Dalam kegiatan sehari-hari selama masa pandemi covid19 pendidikan keterampilan hidup untuk menumbuhkan sikap kemandirian anak dalam kehidupan sehari-hari yang ditanamkan kepada orangtua selama dirumah menanamkan kebiasaan-kebiasaan yang sederhana dan selalu melibatkan anak yang akhirnya menjadi suatu kebiasaan yang dilakukan sehari-hari menjadi rutinitas yang positif. Menurut pendapat hewi (2015:3) kemandirian adalah bagaiamana cara untuk melatih anak untuk mandiri dalam memecahkan masalah dimulai dengan yang sederhana dalam kehidupan sehari-hari dank tidak menggantungkan tehadap oranglain. Dapat diuraikan penting bagi orangtua menanamkan nilai kemandirian pada anak untuk membangun pengetahuan yang positif terhadap apa yang dihadapi anak dapat bertindak dalam mengambil keputusan yang menurutnya terbaik.

\section{SIMPULAN}

Dengan adanya kebijakan pemerintah selama masa pandemi Covid-19 yang menyebabkan seharusnya pembelajaran tatap muka menjadi belajar dan bekerja dari rumah (BDR), peran orangtua sangat berpengaruh besar dalam perkembangan dan pertumbuhan anak, terutama dalam pendidikan keterampilan hidup anak usia dini selama masa pandemi covid-19. Bagaimana peran orangtua dalam kehidupan keluarga mengajarkan anak dalam pembiasaan-pembiasaan (life skill) mengarahkan kepada anak untuk dapat mengimplementasikan dalam kehidupan sehari-hari dengan pembiasaanpembiasaan sederhana seperti belajar disiplin, kemandirian, kreatif sehingga hal tersebut dapat mendorong anak menumbuhkan nilai karakter dalam membentuk pembiasaan. Keteladanan dan kesabaran orangtua dalam membimbing anak adalah suatu kewajiban bagi setiap orangtua melalui belajar dari rumah orangtua juga dapat melihat setiap perkembangan pada anak hal tersebut mengajarkan anak lebih bersikap bertanggung jawab, dapat berfikir kritis, inovatif dan berfikir luwes. Dalam penelitian ini untuk mengetahui kebenaran peneliti mengkaji lebih jauh Keterampilan hidup anak usia dini selama pandemi dirumah dengan menggunakan metode kajian pustaka.

\section{DAFTAR PUSTAKA}

Ahmadi, Abu, 1991. Psikologi Perkembangan. Jakarta: Rineke Cipta. A’yun, Qurrota, Nanik Prihartanti, and Chusniatun Chusniatun. "Peran Orang Tua dalam Pendidikan Anak Usia Dini (Studi Kasus pada Keluarga Muslim Pelaksana Homeschooling)." 
Indigenous: Jurnal Ilmiah Psikologi 13.2 (2016).

Buana, D. R. (2020). Analisis Perilaku Masyarakat Indonesia dalam Menghadapi Pandemi Virus Corona (Covid-19) dan Kiat Menjaga Kesejahteraan Jiwa. Salam: Jurnal Sosial dan Budaya Syar-i, 7(3), 217-226.Cahyati, Kusumah. 2020. Peran Orangtua Dalam Menerapkan Pembeljaran Dirumah Saat Pndemi Covid 19. Jurnal Golden Age. Universitas Hamzanwadi.

Dewi. (2020). Adaptasi Pranata Keluarga Pada Proses Pembelajaran E-Learning Dalam Menghadapi Dampak Pandemi Covid-19. Jurnal Ilmiah Politik, Kebijakan, \& Sosial (Publicio). Vol 2 no 2.

Erzad. (2017). Peran Orangtua Dalam Mendidik Anak Sejak Dini Di Lingkungan Keluarga. Vol 5 No 2

Guntur, N. A., Kasmawati, A., \& Sudirman, M. (2018). Peran Orangtua Dalam Menanamkan Sikap Disiplin Anak Di Desa Kalimporo Kecamatan Bangkala Kabupaten Jeneponto. Jurnal Tomalebbi, (1), 143-154.

Hewi, L. (2015). Kemandirian usia dini di suku bajo. Jurnal Pendidikan Usia Dini, 9(1), 75-92.

Iftitah, Anawaty. (2020). Peran Orangtua Dalam Pendampingi Anak Di Rumah Selama Pandemi Covid-19. JCE (Journal of Childhood Education). VOL (4), NO(2)

Mayar dkk. (2019). Urgensi Profesionalisme Guru Paud Dalam Mengembangan Kreativitas Anak Usia Dini.Jurnal Pendidikan Tambusai.Vol 3 No 5.

Mutiyati, Yuniarti. (2020). Implementasi Pendidikan Pada Masa Covid-19 Dalam Perspektif Sosiologi.Vol 3 No 1 Juli 2020

Noor. (2015). Pendidikan kecakapan Hidup (life skill) di Pondok Pesantren dalam Mengkatkan Kemandirian Santri.Jurnal Empowermen.Vol 3 No 1.

Permono, H. (2013). Peran orangtua dalam optimalisasi tumbuh kembang anak untuk membangun karakter anak usia dini.

Priyanto. (2014). Pengembangan kreativitas pada anak usia dini melalui aktivitas bermain. Jurnal Ilmiah Guru.

Purandina, Winaya. (2020). Pendidikan Karakter di Lingkungan Keluarga Selama Pembelajaran Jarak Jauh pada Masa Pandemi COVID-19.Jurnal Ilmu Pendidikan. Vol 3 no 2

Utami, R. D. (2018). Pendidikan Kecakapan Hidup (Life Skill) Untuk Anak Usia Dini. Sa'diyah. (2017). Pentingnya Melatih Kemandirian Anak.Yogyakarta:Pustaka Pelajar. Sudarsana. (2017). Membentuk Karakter Anak Sebagai Generasi Penerus Bangsa Melalui Pendidikan Anak Usia Dini. Jurnal Purwadita. Vol 1 No 1.

Ta'biin. (2017). Pengelolaan Pendidikan Karakter Disiplin Anak Usia Dini Studi Kasus Di Al-Muna Islamic Preschool Semarang. Awlady: Jurnal Pendidikan Anak.Vol 3 No. 1.

Trisnawati, Sugito. (2021). Pendidikan Anak Dalam Keluarga Era Covid-19.Jurnal Obsesi:Jurnal Pendidikan Anak Usia Dini.Vol. 5 No. 1 